\title{
INTEGRASI KEILMUAN DALAM KRITIK MATAN HADIS
}

\author{
Muhammad Taufiq Firdaus \\ Universitas Islam Negeri Sunan Kalijaga Yogyakarta \\ taufiqfirdaus27@gmail.com
}

\section{Muhammad Alfatih Suryadilaga}

Universitas Islam Negeri Sunan Kalijaga Yogyakarta

muhammad.suryadilaga@uin-suka.ac.id

\begin{abstract}
This article describes about the matan criticisms that have taken place among the scholars of Hadith and its development in the present context. The method of matan hadith criticism can be done by integrating a science. Scientific integration becomes important in completing the hadith especially closely related to science such as camel's urine content as a cure for disease. With the times of rapid development, science is also very developed make the results of research conducted with science, there is no doubt about the truth scientific. This research method uses a qualitative approach with the type of literature review, Data obtained from various literature books, journal articles, theses, and various other research results. The results of this study indicate that Contemporary Muhaditsin scholars make a critique of Matan Hadith by using science, one of them did the critique matan in the book of Bukhari (2855) and Muslim (1671) the hadith about camel's urine, which can cure various diseases. the study showed that camel's urine can prevent the growth of cancer cells. This is the integration of scholarship in the criticism of matan hadis that can make the results of the criticism of matan really convince that the hadith is authentic, although Muslims no doubt in believing the truths of the Prophet's hadith, but here to find out the level of authenticity and validity of Matan Hadith.

Artikel ini menjelaskan tentang kritik matan yang terjadi di kalangan ulama hadis dan pengembangannya dalam konteks kekinian. Metode kritik matan hadis dapat dilakukan dengan meintegrasikan suatu keilmuan. Integrasi keilmuan menjadi penting dalam menyelesaikan hadis-hadis terutama terkait erat dengan sains seperti kadungan air kemih unta sebagai penyembuh penyakit. Dengan perkembangan zaman yang sangat pesat,
\end{abstract}


ilmu sains yang juga sangat berkembang menjadikan hasil-hasil penelitian yang dilakukan dengan keilmuan sains tidak diragukan lagi kebenarannya secara ilmiah. Metode penelitian ini menggunakan pendekatan kualitatif jenis kajian pustaka, data diperoleh dari berbagai literatur buku, artikel jurnal, tesis, dan berbagai hasil penelitian lainnya. Hasil penelitian ini menunjukan bahwa Ulama Muhadditsin kontemporer melakukan kritik matan hadis dengan mengunakan ilmu sains, salah satunya melakukan kritik matan yang ada didalam kitab bukhari (2855) dan muslim (1671) hadis tentang air kemih unta, yang bisa menyembuhkan berbagai penyakit. Penelitian tersebut menunjukan benar bahwa air kemih unta bisa mencegah tumbuhnya sel-sel kanker. Ini lah integrasi keilmuan dalam kritik matan hadis yang bisa membuat hasil hasil dari kritik matan itu benar-benar menyakinkan bahwa hadis itu shahih, walaupun umat Islam tidak diragukan lagi dalam menyakini kebenaran-kebenaran dari hadis nabi tersebut, tetapi disini untuk mengetahui tingkat keotentisitas dan keshahihan sebuah matan hadis.

Keywords: Integrasi Keilmuan, Kritik Matan Hadis, Teks, Konteks, Ijtihad

\section{Pendahuluan}

Kritik matan merupakan salah satu bagian terpenting dari penilaian otentisitas hadis, ${ }^{1}$ dan kemudian dikembangkan menjadi pemahaman hadis. ${ }^{2}$ Matan adalah bagian salah satu unsur sebuah hadis yang juga dapat dilakukan penelitian sebagaimana dalam sanad hadis. Kegiatan ini, di kalangan ulama hadis kurang berkembang dibandingkan dengan penilaian dan kritik atas sanad atau rawi yang di dalam literaur keilmuan sangat beragam dan jumlahnya banyak. ${ }^{3}$ Kritik matan penting dilakukan karena disebabkan oleh dua yakni, banyaknya terjadi pemalsuan hadis yang sudah tersebarkan dimasa periwayatan hadis dan adanya al-wahm yaitu berbagai kekeliruan

1 Suryadi Suryadi, "Rekonstruksi Kritik Sanad Dan Matan Dalam Studi Hadis," Esensia: Jurnal Ilmu-Ilmu Usbuluddin 16, no. 2 (1 Oktober 2015): 177-86, https://doi.org/10.14421/esensia.v16i2.996.

2 Muhammad Asriady, "Metode Pemahaman Hadis," Ekspose: Jurnal Penelitian Hukum Dan Pendidikan 16, no. 1 (13 April 2019): 314-23, https://doi.org/10.30863/ekspose.v16i1.94.

${ }^{3}$ Muhammad Alfatih Suryadilaga, Metodologi Penelitian Hadis (Yogyakarta: Teras, 2009).

154 | TAJDID vol. 18, No. 2, Juli - Desember 2019 
dalam periwayatan hadis. ${ }^{4}$ Penelitian matan dalam berbagai bagian masih terserak dalam beragam kajian sehingga untuk melakukan penilaian menjadi sulit dan membutuhkan bantuan kitab-kitab lain.

Kenyataan di atas melahirkan upaya untuk menjadikan penelitian matan untuk mempermudah sebagaimana yang terjadi di kalangan penelitian sanad. ${ }^{5}$ Kaidah-kaidah peneitian matan akan dapat diformulasikan agar lebih mudah diimplementasikan dalam sebuah penelitian. ${ }^{6}$ Kajian atas tokoh tertentu akan mempermudah memahami hadis seperti kajian atas Muhammad al-Ghazali dan Yusuf al-Qardawi. ${ }^{7}$ Atau mellaui beragam pendekatan lewat tokoh tertentu ${ }^{8} \mathrm{Hal}$ tersebut juga dilakukan pengembangan untuk menjadikan integrasi keilmuan di era kekinian setidaknya dengan menggunakan ilmu-ilmu sosial dan ilmu lain seperti sains dan teknologi.' Selain itu melahirkan beragam tokoh kekinian dengan

${ }^{4}$ Tasmin Tangngareng, "Methodology of Hadith Content Criticism: A Study on the Thought of Salah al-Din Bin Ahmad al-Adlabi," Esensia: Jurnal Ilmu-Imu Ushuluddin 17, no. 1 (1 April 2016): 97-110, https:// doi.org/ 10.14421/esensia.v17i1.1281.

${ }^{5}$ Hedhri Nadhiran, "Kritik Sanad Hadis: Tela'ah Metodologis," Jurnal Imu Agama UIN Raden Fatah 15, no. 1 (2014): 91-109.

${ }^{6}$ Lalu Heri Afrizal, "Selisik Atas Metodologi Kritik Matan Ulama Hadis," Kalimab: Jurnal Studi Agama Dan Pemikiran Islam 14, no. 2 (30 September 2016): 191-218, https://doi.org/10.21111/klm.v14i2.612; T.M.S.T. Ismail dkk., "The matan and sanad criticisms in evaluating the hadith," Asian Social Science 10, no. 21 (2014): 152-58, https://doi.org/10.5539/ass.v10n21p152; Juriono Juriono, "Metode Kritik Matan Mushthafa As-Siba'i Dalam Kitab as-Sunnah Wa Makanatuha Fi at-Tasyri' Al-Islami," AT-TAHDIS: Journal of Hadith Studies 1, no. 1 (31 Maret 2017), http://jurnal.uinsu.ac.id/index.php/ attahdits/article /view / 650.

7 Suryadi Suryadi, Metode Kontemporer Memahami Hadis Nabi Perspektif Muhammad al-Ghazali dan Yusuf al-Qardhawi (Yogyakarta: EISAQ Press, 2008).

${ }^{8}$ Ahmad Syahroni, "Pembahasan Metode Pemahaman Hadis Imam Syafi'i," Aktualita: Jurnal Penelitian Sosial Keagamaan 9, no. 1 (24 Juli 2019): 1-16; Amrulloh Amrulloh, "Kontribusi M. Syuhudi Ismail Dalam Kontekstualisasi Pemahaman Hadis," Mutawatir: Jurnal Keilmuan Tafsir Hadith 7, no. 1 (1 Juni 2017): 76-104, https://doi.org/10.15642/mutawatir.2017.7.1.76-104; Hasanuddin Sinaga, "Metode Pemahaman Hadis Ulama Mutaqaddimīn (Tinjauan terhadap Metode Pemahaman Ahli Hadis dan Fuqahā')," Refleksi 18, no. 1 (24 September 2019): 66-77, https://doi.org/10.15408/ref.v18i1.12676.

9 Muhammad Alfatih Suryadilaga, Ulumul Hadis (Yogyakarta: kalimedia, 2015).

TAJDID vol. 18, No. 2, Juli - Desember 2019 | 155 
model hermeneutikanya seperti Fazlur Rahman, ${ }^{10}$ Muhammad Arkoun, ${ }^{11}$ Khali Abou Fadl, ${ }^{12}$ Nasr Hamid Abu Zaid, ${ }^{13}$ Hassan Hanafi, dan lain-lain. Dengan demikian, kajian penelitian matan menjadi berkembang dan menarik.

Artikel ini menjelaskan tentang integrasi keilmuan dalam kritik hadis. Bagaimana makna kritik matan dan kaidah yang digunakan oleh ulama ahli hadis dan bagaimana integrasi keilmuan dalam menilai kualitas sebuah matan hadis. Kajian tersebut kemudian dijelaskan lewat pengertian kritik matan, metode kritik matan dan integrasi keilmuan dalam kritik matan. Ketiga bahasan tersebut akan dijelaskan dengan deskriptif analisis sesuai dengan keilmuan yang dibangun ulama muhaddisin. Selain itu, untuk menjadikan kajian ini menarik akan dijelaskan dan dianalisis sesuai dengan perkembangan ilmu pengetahuan.

Kritik matan hadis masih tertuju tekstual, dalam artian teks nya shahih atau tidak. Dengan berkembangnya zaman kegitan kritik

10 Alma'arif Alma'arif, “Hermeneutika Hadis Ala Fazlur Rahman,” Jurnal Studi Ilmu-Imu Al-Qur'an Dan Hadis 16, no. 2 (2015): 243-64, https://doi.org/10.14421/qh.2015.\%x.

11 Baedhowi Baedhowi, "Islamologi Terapan Dan Problema Aplikasinya: (Mengkaji Pemikiran Mohammed Arkoun)," Al-jami'ab: Journal of Islamic Studies 41, no. 1 (16 Juni 2003): 133-52, https://doi.org/10.14421/ajis.2003.411.133152; Zailani Zailani, "Rekontruksi Tradisi Islam (Studi Pemikiran Muhammed Arkoun Tentang Sunnah)," Jurnal Ushuluddin 18, no. 2 (1 Desember 2012): 198207, https://doi.org/10.24014/jush.v18i2.709.

12 Ihab Habuddin, "Konstruksi Gagasan Feminisme Islam Khaled M. Abou El-Fadl: Relevansinya Dengan Posisi Perempuan Dalam Keluarga," Al-Abwal: Jurnal Hukum Keluarga Islam 5, no. 2 (26 September 2016): 1-30; Ahmad Suhendra, "Hermeneutika Hadis Khaled M. Abou El Fadl," Mutawatir 5, no. 2 (1 Desember 2015): 343-62, https://doi.org/10.15642/mutawatir.2015.5.2.343-362; Abdul Majid, "Hermeneutika Hadis Gender (Studi Pemikiran Khaled M. Abou El Fadl Dalam Buku Speaking in God's Name; Islamic Law, Authority And Women)," Al-Ulum 13, no. 2 (1 Desember 2013): 293-320.

13 N.Z.N. Zainol dan L.A. Majid, "Studied controversial issues and analyze Nasr Hamid Abu Zayd thoughts contained in voice of exile: Reflections on Islam," Advanced Science Letters 23, no. 5 (2017): 4951-54, https://doi.org/10.1166/asl.2017.8973; Nasrulloh Nasrulloh, "Kontekstualitas dan Historisitas Matan Hadis-Hadis Peperangan Terhadap Non-Muslim," Jurnal THEOLOGLA 28, no. 1 (14 September 2017): 165-82, https://doi.org/10.21580/teo.2017.28.1.1322. 
matan bisa dilakukan dengan meintegrasikan keilmuan masa kini, yakni sosial Humaniora dan Sains. ${ }^{14}$ Pengintegrasian ini bertujuan untuk mengetahui kebenaran dari teks matan hadis tersebut. Contohnya kritik matan hadis tentang air kemih unta, dalam kritik matan hadis tersebut menggunakan ilmu sains untuk mengujinya. Dari hasil penelitian dari para ilmuan-ilmuan dan dokter muslim menunjukkan kebenaran matan hadis tersebut. Memang benar bahwa air kemih unta bisa untuk mengobati berbagai penyakit. ${ }^{15}$

Kajian kritik matan hadis dalam atikel ini merupakan kajian yang menjadi inti dalam otentitas hadis. Namun, dalam kajian tersebut hanya terfokuskan pada matan hadis. Penelitian atas matan hadis dapat dikelompokkan sebagai berikut, kritik matan sebagai sebuah teoritis yaitu dikaji dengan integrasi ilmu-ilmu sosial humaniora dan integrasi ilmu sains. ${ }^{16}$ Sedangkan kajian lain yang cukup banyak adalah penelitian tentang praktek penelitian matan. Hal tersebut sebagaimana dilakukan oleh kebanyakan sarjanasarjana hadis yang menulis tentang metode dalam kritik matan hadis, kebanyakanya hanya menawarkan metode-metode kritik matan hadis dari ulama-ulama yang sudah membuat kitab tentang metode kritik matan hadis. ${ }^{17}$

${ }^{14}$ Mohd Yusuf Ismail, "Peranan Sains Moden Dalam Interaksi Teks Hadis: Penelitian Terhadap Hadis Berkaitan Penciptaan Janin Manusia," Journal Of Hadith Studies 1, no. 1 (31 Desember 2016), http://journalofhadith.com/index.php/johs/article/view/4; M. Idham Aditia Hasibuan, "Kontribusi Sains Dalam Menentukan Kualitas Hadis," EDURILIGIA: Jurnal Ilmu Pendidikan Islam Dan Keagamaan 1, no. 3 (17 Oktober 2017), http://jurnal.uinsu.ac.id/index.php/eduriligia/article/view/955.

${ }^{15}$ Fitri Sari, "Urine unta (studi nalar hadisdan pendekatan medis)," 2018. Universitas Islam Negeri Sumatea Utara Medan. Retrieved from http:// repository.uinsu.ac.id

16 Benny Afwadzi, "Membangun Integrasi Ilmu-Ilmu Sosial Dan Hadis Nabi," Jurnal Living Hadis 1, no. 1 (May 6, 2016): 101-128, accessed November 4, 2019, http:// ejournal.uin suka. ac.id/ ushuluddin /Living/ article/view/1070.

${ }^{17}$ Muhammad Qomarullah, "Metode Kritik Matan Hadis Muhammad Tahir Al-Jawabi Dalam Kitab: Juhud al-Muhaddisin Fi Naqd Matan al-Hadis an-Nabawi Asy-Syarif," Al Quds: Jurnal Studi Alquran Dan Hadis 2, no. 1 (1 Juni 2018): 51-64, https://doi.org/10.29240/alquds.v2i1.390. 
Kajian lain adalah dalam bentuk pemikian atas pentingnya integrasi keilmuan. ${ }^{18}$ Namun, banyak di antara kajian yang ada cenderung penelitian matan tanpa menggunakan integrasi keilmuan. Hal tersebur menjadikan penelitian tentang kritik matan hadis tidak begitu menarik untuk di telaah di zaman sekarang, kajian matan hanya berkisar tentang metodologi kritik matan hadis tanpa mengunakan integrasi keilmuan seperti sosial humaniora dan sains ${ }^{19}$. Peneitian lain adalah dalam konsep integrasi secara umum bukan dalam konteks pelitian matan. Artinya, integrasi hanya dalam pemahaman hadis. Padahal, penelitian matan ini adalah penelitian yang penting karena terait diterima atau tidakanya sebuah informasi yang ada dalam sebuah hadis. Hal ini merupakan kelebihan dan kontribusi artikel yang dikaji yakni terkait erat penelitian matan yang dilaksanakan dengan membuat koridor yang mudah dan mengintegrasikan dalam sebuah konsep dan sekaligus dapat dijadikan model penelitian matan yang mudah.

\section{Metodologi Penelitian}

Metode penelitian dalam artikel ini menggunakan pendekatan kualitatif dengan jenis penelitian kepustakaan atau kajian literatur (library research). Kajian artikel ini lebih focus pada integrasi keilmuan dalam kritik matan hadis. Data yang digunakan dalam penelitian ini bersumber dari berbagai, artikel jurnal, buku, hasil penelitian-

18 M. Amin Abdullah, "Religion, Science, and Culture: An Integrated, Interconnected Paradigm of Science," Al-Jami'ah: Journal of Islamic Studies 52, no. 1 (8 Juni 2014): 175-203, https://doi.org/10.14421/ajis.2014.521.175-203; Muhammad Amin Abdullah, "Islamic Studies in Higher Education in Indonesia: Challenges, Impact and Prospects for the World Community," Al-Jami'ab: Journal of Islamic Studies 55, no. 2 (15 Desember 2017): 391-426, https://doi.org/10.14421/ajis.2017.552.391-426; M. Amin Abdullah, Islamic studies dalam paradigma integrasi-interkoneksi: sebuah antologi (Yogyakarta: SUKA Press, 2007); M. Amin Abdullah, "Multidisiplin, Interdisiplin, dan Transdisiplin Ilmu Pengetahuan dan Riset pada Pendidikan Tinggi Masa Depan," dalam Prosiding Konferensi Integrasi-Interkoneksi Islam dan Sains, vol. 1 (Konferensi IntegrasiInterkoneksi Islam dan Sains, Yogyakarta: Fakultas Sains dan Teknologi UIN Sunan Kalijaga Yogyakarta, 2018), xi, sunankalijaga.org/prosiding.

${ }^{19}$ Fadhli Lukman, "Integrasi-Interkoneksi Dalam Studi Hadis Disertasi Di Uin Sunan Kalijaga Yogyakarta," RELIGLA, 20 Februari 2017, 1-11, https://doi.org/10.28918/religia.v19i2.746. 
penlitian dan berbagai sumber literatur lainnya yang menkaji dalam ruang lingkung kritik matan hadis. Data yang sudah didapatkan akan diolah dan dianalisis dengan diskriptif yaitu bagaimanakah integrasi keilmuan dalam kritik matan hadis. Model data yang diperoleh terkait kritik matan ini kemudian dilakukan pola pendekatan dengan mengunakan intergrasi interkoneksi yang dijadikan kajian dalam pemahaman hadis di Perguruan Tinggi, khususunya dalam mengkaji hadis agar tidak cenderung tekstualis dan liberal.

\section{Pembahasan}

\section{Pengertian Kritik Matan}

Matan hadis sebagai bagian terpenting dari sebuah hadis. Hal tersebut setidaknya melalui matan inilah informasi kegaamaan diperoleh. Hal ini juga merupakan bagian dari pertintah Allah swt. sebagaiana dalam Q.S. al-Nisa (4): 80 : bahwa ketaatan seseorang kepada Rasulnya maka sesungguhnya dia telah mentaati Tuhannya. Dengan demikian, matan menjadi penting untuk di kaji untuk memahami isi dan kandunganya guna memperoleh keotentisitasnya sebagai sumber ajaran agama Islam kedua setelah Al-Qur'an alKarim. ${ }^{20}$ Matan menurut bahasa Arab yang artinya ialah punggung jalan atau tanah yang keras dan tinggi. Yang dimaksud matan dalam ilmu hadis adalah ma yantabiy ilaybi as-sanad min al-kalam, yakni sabda Nabi yang disebut setelah sanad, atau penghubung sanad, atau materi hadis. ${ }^{21}$ Matan adalah isi hadis, matan hadis terbagi tiga, yaitu ucapan, perbuatan, dan ketetapan Nabi Muhammad Saw. ${ }^{22}$

Bila kritik hadis yang dimaksud adalah usaha untuk membedakan yang benar dan salah, maka kegiatan kritik hadis ini dapat dikatakan sudah dilakukan semenjak masa hidup Nabi Muhammad saw, dalam artian pengecekan kebenaran bisa langsung dilakukan dengan langsung menanyakannya kepada Nabi saw. Pada masa nabi kritik matan sangat mudah dilakukan, karena keputusan

${ }^{20}$ Suryadi, "Rekonstruksi Kritik Sanad Dan Matan Dalam Studi Hadis."

21 Alfatih Suryadilaga, Ulumul Hadis, 36.

22 Bustamin, M. Isa H.A. Salam, Metodologi kritik hadis (jakarta: PT RajaGrafindo Persada, 2004), 59.

TAJDID vol. 18, No. 2, Juli - Desember 2019 | 159 
keotentisitas sebuah matan berada di tangan nabi sendiri. Kritik matan hadis dilakukan untuk menguji keabsahan suatu matan hadis, dan untuk memisahkan antara matan-matan hadis yang sahih dan yang tidak sahih. Dengan demikian kritik matan hadis bukan untuk menggoyahkan atau mengoreksi sumber ajaran Islam dengan mencari kelemahan sabda Nabi Muhammad saw, akan tetapi untuk menelaah redaksi dan makna hadis untuk menetapkan keabsaahan suatu matan hadis. Oleh karena itu kritik matan hadis merupakan upaya positif untuk menjaga kemurnian sebuah matan hadis, disamping juga untuk lebih memberikan pemahaman yang lebih tepat terhadap hadis Nabi Muhammad saw. ${ }^{23}$

Dari masa ke masa studi hadis memang terus dilakukan oleh para ulama-ulama, terlebih dimasa modern saat ini. perhatian ulama tentang hadis kemudia terfokuskan tentang matan hadis. Hal ini sejalan dengan besarnya umat Islam dalam kritik hadis dari segi matannya tidak hanya dari segi sanad. Diantara ulama-ulama yang menulis kitab tentang pembahasan, penjelasan dan persoalan kritik matan hadis ialah Muhammad Thahir Al-Jawabi menulis Jubud alMubadditsin fi Naqd Matn al-Hadits al-Nabawi al-Syarif. ${ }^{24}$ Muhmaad Mustafa al-Azami menulis Manhaj an-Naqd Inda al-Mubadditsin, Shalah Al-Din ibn Ahmad Al-Adabi menulis Manhaj Naqd al-Matn Inda 'Ulama' al-Hadits al-Nawawi, dan Yusuf Qardawi menulis Kayfa Natamal ma'a al-Sunnab al-Nabawiyah. ${ }^{25}$ yang didalamnya menawarkan tentang metodologi penelitian kritik matan hadis dan berupaya memberikan solusi matan-matan hadis yang bersebrangan dengan sumber hukum yang lain.

\section{Metode Kritik Matan}

Kritik matan dilaksanakan oleh ulama hadis dengan mengikuti langkah-langkah tertentu yang sangat subyektif. Kritik matan lazim dikenal dengan al-naqd al-dakblili kritik intern. Istilah ini dikaitkan dengan orintasi kritik matan itu sendiri, yakni difokuskan kepada

${ }^{23}$ Umi Sumbulah, Kritik Hadis Pendekatan Historis Metodologis (malang:UINMalang Press, 2008), 94.

${ }^{24}$ Qomarullah, "Metode Kritik Matan Hadis Muhammad T?"

${ }^{25}$ Sumbulah, Kritik. Hadis Pendekatan Historis Metodologis.

160 | TAJDID vol. 18, No. 2, Juli - Desember 2019 
teks intisari dari hadis Nabi, yang ditransmisikan dari zaman nabi sampai pada geberasi-generasi berikutnya hingga ke tangan para mukharij al-hadis, baik secara lafdzi maupun ma'nawi. ${ }^{26}$ Para muhadditsin memberikan teori dan menetapkan dua kriterian dalam menilai kesahihan pada matan hadis, dua kriteria tersebut yakni terbebasnya matan hadis tersebut dari unsur syadz dan illah. ${ }^{27}$ Ada perbedaan dikalangan ulama mengenai Pengertian syadz, diantarnya Imam al-Syafi'i, al-Khalili dan al-Hakim. Syadz menurut Imam alSyafi'i yakni suatu hadis yang diriwayatkan oleh seorang tsiqoh yang bertentangan dengan hadis yang diriwayatkan oleh orang-orang (yakni perawi siqah lainnya). ${ }^{28}$

Secara garis besar dalam melakukan kritik matan hadis harus melakukan tiga tahapan yaitu. Pertama, melakukan kritik atau seleksi matan hadis (naqdu al-matan). kedua, menginterpretasi makna matan hadis (syarh al-matan). Ketiga melakukan tipologi atau klasifikasi matan hadis (qism al-matan). Menurut Muhammad Tahir Al-Jawabi di dalam kitabnya yang berjudul Jubüd al-Muhaddisin Fì Naqd Matan al-Hadïs an-Nabawi asy-Syarif menyatakan bahwa tahapan-tahapan yang penting dalam melakukan kritik hadis secara umum sebagai berikut; Mengumpulkan keterangan hadis, Melakukan kritik perawi, Kehati-hatian dalam meriwayatkan hadis, Melakukan kritik makna hadis, Mencari sanad hadis, Membuat pondasi ilmu jarh wa ta'dil, Membahas 'ilal al-hadits, Penelitian makna hadis untuk menolak perentangan hadis dan kemuskilan, Melakukan kritik bahasa hadis, Menjelaskan fiqih hadis. ${ }^{29}$

Menurut Al-Adlabi metode kritik matan yakni; pertama, tidak bertentangan dengan al-Qur'an al-Karim. Kedua, tidak bertentangan

${ }^{26}$ Khabibi Muhammad Luthfi, "Kritik Matn Sebagai Metode Utama dalam Penelitian Kesahihan Hadis Nabi," Islamic Review: Jurnal Riset dan Kajian Keislaman 4, no. 2 (2015): 199-224.

${ }^{27}$ Hairul Hudaya, "Metodologi Kritik Matan Hadis Menurut Al-Adlabidari Teori ke Aplikasi," Jurnal Ilmiab Ilmu Ushuluddin 13, no. 1 (2016): 29-40.

28 Aan Supian, "Konsep Syadz Dan Aplikasinya Dalam Menentukan Kualitas Hadis," Nuansa 8, no. 2 (14 Desember 2015), https://doi.org/10.29300/nuansa.v8i2.396.

${ }^{29}$ Qomarullah, "Metode Kritik Matan Hadis Muhammad T?"

TAJDID Vol. 18, No. 2, Juli - Desember $2019 \mid 161$ 
dengan hadis dan sirah nabawiyah yang shahih. Ketiga, tidak bertentangan dengan akal, indera dan sejarah. Keempat, mirip dengan sabda kenabian. Pendapat Al-Adlabi ini hasil ringkasan dari kriterian-kriteria keshahihan matan hadis menurut Ibn Qayyim dan al-Bagdadi. ${ }^{30}$ Tujuan dari penelitian kritik matan hadis ialah bahwa matan hadis adalah sesuatu yang penting untuk dijaga keotentitasnya. Alasan ini terkait dengan pentingnya menjaga kemurnian agama dengan menjaga hadis sebagai warisan Nabi yang dijadikan sebagai sumber kedua umat Islam. Tujuan dari kritik matan ini juga dipengaruhi karena banyaknya periwayatan Bi al-ma'na periwatan dengan makna menimbulkan banyak interpretasi, oleh karena itu periwatan dengan makna menuntut pemikiran lebih panjang terhadap makna hadis. ${ }^{31}$

Contoh kritik matan yang sudah dilakukan oleh ulama yakni matan hadis tentang manfaat air susu dan air kemih unta untuk mengobati berbagai penyakit, kritik matan hadis ini sudah dilakukan dari ulama-ulama yang terdahulu hingga ulama-ulama muhaditsin kontemporer. Metode kritik yang digunakan juga mengacu kepada metode kritik matan yang sudah dibakukan oleh ulama-ulama muhaditsin terdahulu, yakni sebelum meneleliti matan terlebih dahulu harus melihat kualitas sanadnya, meneliti susunan atau lafal matan yang semakna dan yang terakhir meneliti isi makna kandungan matan tersebut. Para ilmuan-ilmuan muslim modern saat ini dalam penelitian matan tersebut menekankan pada makna kandungan matan, para ilmuan ini menggunakan ilmu sains dalam membuktikan kebenaran matan hadis tersebut.

Didalam Journal of Ethnopharmacology mempublikasikan hasil penelitian Najoud Al Yousef pada tahun 2012, Najoud Al Yousef meneliti tentang urine unta, hasil penelitian tersebut menunjukkan bahwa urine unta terbukti mematikan sel-sela kanker manusia, mengkonsumsi $2016 \mathrm{mg} / \mathrm{ml}$ urine unta yang telah dikeringkan

30 Ṣalāḥ al-Dīn ibn Aḥmad Idlibī, Metodologi kritik matan hadis (Gaya Media Pratama, 2004).

${ }^{31}$ Norhidayati Salamah, Kritik Teks Hadis: Analisis Tentang ar-Riwayah bi alMa'na dan Implikasinya bagi Kualitas Hadis (Yogyakarta: teras, 2009).

162 | TAJDID vol. 18, No. 2, Juli - Desember 2019 
dengan cara freeze drying terbukti mampu menghambat perkembangan sel kanker. (Najoud Al Yousef dkk, "Camel urine components display anti-cancer properties in vitro," dalam Journal of Ethnopharmacology, vol. 143. 819.)

\section{Integrasi Keilmuan Sosial Humaniora dan Sains}

Ilmu sosial, arti ilmu secara bahasa adalah pengetahuan sedangkan sosial memiliki banyak arti. Menurut soekanto arti sosial dalam ilmu sosial adalah masyarakat, yaitu merujuk pada objek dari ilmu sosial itu. Dengan demikian dapat disimpulkan bahwa yang dimaksud dengan ilmu sosial adalah ilmu yang mengkaji tentang masyarakat. ${ }^{32}$ didalam ilmu sosial (sosial sciences) tidak ada kata kebenaran pasti, berbeda dengan ilmu alam (natural sciences) ilmu alam mengunakan ukuran matematis yang pasti untuk menghasilkan sebuah ilmu pengetahuan sebagai kebenaran tunggal. Objek ilmu sosial adalah masyarakat atau manusia itu sendiri hal ini yang menjadikan ilmu sosial tidak mengenal kebenaran yang tunggal. Bisa jadi disebuah masyarakat sesuatu itu benar dimasyarakat lain memandang itu salah.

Al-Qur'an dan Hadis berasal dari Allah swt dan Nabi Muhammad saw sebagai pembuat syariat dan sumber utama ajaran Islam, kemudian setelah itu disampaikan oleh Nabi kepada ummatnya maka pemahaman terhadap ajaran Islam tersebut dipahamai dan dilaksanakan oleh oleh seluruh umat manusia, sehingga manusia mempunyai peran penuh dalam menterjemahkan dan meinterpretasikan dengan berbagai metode dan cara. Dari hasil interpretasi itu muncul lah ilmu-limu agama seperti Tafsir, Hadis, Tasawuf, Kalam, Fikih. Paradigma yang diusung disini adalah penggabungan antara teosentris dengan teo-antroposentris yaitu penggabungan dua dimensi pengetahuan yang berbeda antara dimensi ketuhanan dan kemanusiaan. ${ }^{33}$

32 Soejono Soekanto, Sosiologi: Suatu Pengantar (Jakarta: Raja Grafindo Persada, 2012), 13.

33 Azhar Arsyad, "Buah Cemara Integrasi dan Interkoneksitas Sains dan Ilmu Agama," Hunafa: Jurnal Studia Islamika 8, no. 1 (2011): 1-25.

TAJDID vol. 18, No. 2, Juli - Desember 2019 | 163 
Dalam memahami dan meninterpretasi hadis Nabi tidak hanya berhenti pada upaya kritik eksternak (sanad) dan internal (matan), tetapi harus lebih komprehensif yang harus dikolaborasikan dengan pendekatan historis. Hal ini mengapa menjadi penting, karena kesejarahan Nabi dengan masa sekarang sudah berbeda. Hasil dari usaha ini adalah agar diketahui latar belakang dan historis kemunculan sebuah hadis, yang kemudian dapat dipahami bagaimana penerapanya dizaman sekarang ini. Untuk mencapai upaya tersebut maka sangat penting menggunakan piranti keilmuan sosial, seperti Sejarah, Antropologi dan Sosiologi dalam memahami hadis Nabi. ${ }^{34}$ Sejarah akan menjelaskan situasi empiris masyarakat arab saat itu, Antropologi menjelaskan keadaan manusia dan praktek keagamaan yang sedang terjadi di Arab saat itu, dan Sosiologi akan membahas masyarakat Arab dan kondisi konstruksi sosialnya.

Masa sekarang ini menghendaki penyatuan dalam berbagai bidang keilmuan yang mempunyai dimensi berbeda. Ilmu agama yang mempunyai dimensi ketuhanan diharapkan dapat berintegrasi dengan ilmu-ilmu eksakta maupun sosial humaniora dan sains yang berdimensi kemanusiaan. ${ }^{35}$ Dengan penyatuan anatara ilmu-ilmu sosial amupun ilmu alam dengan teks keagamaan pada intinya diharapkan dapat memberikan dan menciptakan solusi dari berbagai problem kekinian sekaligus memperkuat bukti-bukti kebenaran dari teks-teks agama, khususnya agama Islam. Dengan integrasi keilmuan ini pemecahan masalah sosial bisa dikaji dan di carikan solusi dari teks-teks agama seperti matan hadis. Masalah sosial bisa dikaji dalam bidang ilmu sosiologi dengan menungkapkan fakta data bahwa masalah sosial yang kekinian diantaranya adalah kemiskinan, kejahatan, kenakalan remaja, korupsi, dan lain sebagainya kemudian untuk mencari solusi bisa mengkaji sebuah hadis-hadis yang

34 Benny Afwadzi, "Hadis di Mata Para Pemikir Modern: Telaah Buku Rethinking Karya Daniel Brown,” Jurnal Studi Ilmu-Ilmu al-Qur'an dan Hadis 15 (2014): 238.

35 Afwadzi, "Membangun Integrasi Ilmu-Ilmu Sosial Dan Hadis Nabi," 106.

164 | TAJDID vol. 18, No. 2, Juli - Desember 2019 
menyangkut masalah itu. Dengan demikian integrasi keilmuan pasti berjalan dengan baik dan menghasilkan solusi yang tepat. ${ }^{36}$

Integrasi kritik matan hadis dengan sains, ilmu sains adalah cara untuk mempelajari aspek-aspek sesuatu dari alam dengan terorganisir, sistematis dengan mengunakan metode saintific yang sudah terbakukan ${ }^{37}$. Hasil dari sains itu muncul lah ilmu-ilmu seperti kedokteran dan matematika, ilmu matematika merupakan ilmu pokok untuk mempelajari ilmu sains seperti kimia, fisika, astronomi, geografi, biologi dan sebainya. ${ }^{38}$ Pengaplikasian dari integrasi keilmuan kritik matan hadis dapat dilihat didalam kitab hadis bukhari (2855) dan muslim (1671) didalam hadis tersebut Nabi bersabda menjelaskan tentang manfaat air kemih dan air susu unta, bahwa air kencing dan air susu unta bisa menjadi obat untuk menyembuhkan berbagai penyakit. Pembahasan tentang manfaat air kemih unta sebenarnya sudah lama dibahas oleh ilmuan-ilmuan muslim seperi Ibnu sina, Ibnu Taimiyah, Ibnu Qayyim al-jauzi, ArRazi dan lain-lain. Pada masa modern pembahasan ini kembali diteliti oleh ulama, cendikiawan, peneliti-peneliti muslim dengan menggunakan ilmu sains, dan hasilnya pun memang benar, bahwa air kemih unta mengandung berbagai komposisi kimia yang berguna untuk mengobati penyakit kanker. Abdul Qader Al-Haider dalam penelitianya yang diterbitkan Journal of Ethopharmacology, bahwa air kemih unta yang masih belum dikawinkan mampu menghambat induksi ekspresi gen cytochrome p450 1A1, yang menghambat pertumbuhan sel kanker manusia. ${ }^{39}$

36 Benny Afwadzi, "Integrasi ilmu-ilmu alam dan ilmu-ilmu sosial dengan pemahaman hadis Nabi: Telaah atas konsepsi, aplikasi, dan implikasi," Theologia 28, no. 2 (Desember 2017): 351-90.

37 Sora N, "Pengertian Sains Secara Singkat Dan Jelas," Pengertian Apapun (blog), 25 Januari 2015, http://www.pengertianku.net/2015/01/pengertiansains-secara-singkat-dan-jelas.html.

38 Ainol Yaqin, "Integrasi Ilmu Agama Dan Sains (kajian Atas Pemikiran AlGhazālī)," Islamuna: Jurnal Studi Islam 3, no. 1 (1 Juli 2016): 37-55, https://doi.org/10.19105/islamuna.v3i1.946.

39 Syed Rizwan Ahamad et al., "Metabolomic and Elemental Analysis of Camel and Bovine Urine by GC-MS and ICP-MS," Saudi Journal of Biological 
Berbagai karya ilmiah lainya yang menunjukkan integrasi keilmuan dalam kritik matan hadis dengan bidang ilmu sosial dan ilmu sains. Diantara contoh hasil kritik hadis yang menggunakan ilmu sosial yakni kajian yang dilakukan oleh Nasri Akib yang mencoba melihat kritik sanad dan matan dengan ilmu sosial, ${ }^{40} \mathrm{Nizar}$ Ali yang memberikan pendekatan ilmu sosial dalam memahami hadis, ${ }^{41}$ M Syuhudi Ismail yang memberikan gambaran dalam mengkaji kritik sanad dengan pendekatan sejarah, ${ }^{42}$ Aceng Abdul Qodir yang mencoba melihat fenomena periwayatan hadis secara politik, ${ }^{43}$ Luqmanul Hakim yang mencoba membaca fenomens inkar al-sunnah secara historis, ${ }^{44}$ Suryadi mengulas pentingnya memahami hadis dengan mempertimbangkan setting historis ${ }^{45} \mathrm{M}$. Alfatih Suryadilaga yang menjelaskan hadis dari kelimuan atropologi, ${ }^{46}$ Adapaun kajian ilmu hadis dengan menggunakan ilmu alam atau sains diantaranya karya Erfan Soebahar dkk. yang mengulas rahasia buah kurma dan zaitun dari perspektif ilmu sains, ${ }^{47}$ Mohd Yusuf Ismail dan Abdul Kareem Toure yang membuktikan kebenaran

Sciences 24, no. 1 (January 1, 2017): 23-29, accessed November 8, 2019, http://www.sciencedirect.com/science/article/pii/S1319562X15001965.

40 Nasri Akib, "Kesahihan Sanad Dan Matan Hadits: Kajian Ilmu-Ilmu Sosial," Shautut Tarbiyah 15, no. 1 (1 Mei 2009): 102-19, https://doi.org / 10. 31332/str.v15i1.103.

${ }^{41}$ Nizar Ali, "Memahami Hadis Nabi: Metode dan Pendekatan," Yogyakarta: Center for Educational Studies and Development (CESaD) YPI Al-Rahmah, 2001.

${ }_{42}$ Muhammad Syuhudi Ismail, Kaedah kesabihan sanad hadis: telaab kritis dan tinjauan dengan pendekatan ilmu sejarah (Bulan Bintang, 1988).

43 Aceng Abdul Kodir, "Hadis dan Analisis Aliran Politik Rijal: Studi GeoPolitik Terhadap Aliran Shi 'ah dan Nasb," Journal of Qur'an and Hadith Studies 1, no. 2 (2012): 277-95.

44 Luqmanul Hakim, "Fenomena Inkar Sunnah dalam Perkembangan Sejarah,” Innovatio VII, no. 14 (2008): 346-64.

45 Suryadi Suryadi, "Pentingnya Memahami Hadis Dengan Mempertimbangkan Setting Historis Perspektif Yūsuf Al-Qaraḍawī," Jurnal Living Hadis 1, no. 1 (6 Mei 2016): 29-50, https://doi.org/10.14421/ livinghadis.2016.1067.

46 Muhammad Alfatih Suryadilaga, "Pembacaan Hadis Dalam Perspektif Antropologi," Al Qalam 34, no. 2 (2017): 265-86.

47 Erfan Soebahar, Edi Daenuri, dan Arizal Firmansyah, "Mengungkap Rahasia Buah Kurma Dan Zaitun Dari Petunjuk Hadis Dan Penjelasan Sains," Ulul Albab Jurnal Studi Islam 16, no. 2 (2015): 191-214.

166 | TAJDID vol. 18, No. 2, Juli - Desember 2019 
hadis Nabi tentang perkembangan embrio dan penciptaan janin manusia, ${ }^{48}$. Adapaun karya dari Dale F. Eickelman dkk mencoba meneliti hadis dengan ilmu sosial dan ilmu alam sekaligus, dalam karyanya mencoba mengumpulkan berbagai tema terkait al-Qur'an dan Hadis dengan sains dan sosial, ${ }^{49}$

\section{Integrasi Keilmuan dalam Kritik Matan Hadis}

Pembahasan integrasi keilmuan dalam matan hadis ini pada hakikatnya adalah gambaran sedikit dari proyek besar integrasi agama dan ilmu. Integrasi keilmuan ini bertujuan untuk menggambarkan bahwa Islam tidak ada dikotomi anatara agama dan ilmu umum. Keduanya tidak boleh (separated) yakni berdiri sendiri secara terpisah, tetapi harus berintegrasi saling melengkapi dan bersama-sama memecahkan persoalan umat secara komprehensif. Melakukan kritik matan sebernarnya sudah dilakukan sejak zaman Nabi, untuk mengetahui keaslian matan hadis yang benar-benar dari Nabi. Seiring berjalanya waktu sampai berabad-abad lamanya maka para ulama yang ingin meneliti suatu matan hadis yang sahih mustahil menannyakan langsung kepada Nabi. Maka para ulama membuat metodologi dasar untuk melakukan kritik sebuah matan hadis, pertama tidak bertentangan dengan Al-Qur'an, kedua tidak bertentangan dengan hadis yang lebih kuat, ketiga tidak bertentangan dengan fakta sejarah dan tidak bertentangan dengan kebenaran ilmiah. ${ }^{50}$

Para muhaditsin kontemporer melakukan kritik sebuah matan hadis dengan menggunakan metodologi tersebut, apalagi zaman sekarang ilmu sains sudah sangat maju, maka para ulama muhaditsin menekankan poin metodologi kritik matan hadis yang terakhir yaitu tidak bertentangan dengan kebenaran ilmiah, maka dengan bantuan ilmu sains yang kebenaran ilmiahnya tidak diragukan lagi, hasil dari kritik matan hadis yang sudah diteliti dengan sains akan lebih meyakinkan para ulama muhaditsin yang meneliti maupun

48 Mohd Yusuf Ismail, "Peranan Sains Moden dalam Interaksi teks Hadis: Penelitian Terhadap Hadis Berkaitan Penciptaan Janin Manusia," 2016.

${ }^{49}$ Dale F Eickelman, “dkk, al Qur’an Sains, dan Ilmu Sosial,” 2010.

${ }^{50}$ Suryadi, "Rekonstruksi Kritik Sanad Dan Matan Dalam Studi Hadis."

$$
\text { TAJDID Vol. 18, No. 2, Juli - Desember } 2019 \text { | } 167
$$


masyarakat secara luas akan sangat menyakini kebenaran dari hadis Nabi tersebut, walaupun umat Islam tidak diragukan lagi dalam menyakini kebenaran hadis-hadis dari Nabi saw. Tetapi disini untuk lebih menguatkan tingkat keshahihan hadis.

Matan hadis yang diriwayatkan oleh Imam At-Tirmizi إنَْرَبُوا مِنَ dan juga diriwayatkan didalam shahih bukhari dan muslim tentang kandungan air susu dan air kemih unta yang dapat menyembuhkan berbagai penyakit. Para muhaditsin dan penelitipeneliti muslim mengkeritik matan ini dengan melakukan penelitian menggunakan bantuan ilmu sains, hasil dari penelitian tersebut memang menunjukkan bahwa air susu dan air kemih unta dapat menyembuhkan berbagai penyakit. Telah banyak penelitian yang dilakukan, tidak hanya dari para ulama muhaditsin yang meneliti matan hadis tentang manfaat air susu dan air kemih unta ini, bahkan para dokter, insiyur kimia, dosen-dosen kedokteran di timur tengah meneliti kandungan air kemih unta tersebut.

Para ulama muhaditsin terdahulu seperti imam bukhari, imam muslim, imam At-Tirmizi dan para ulama-ulama muhaditsin lainya telah mengkritik matan ini dengan melihat kualitas sanadnya dan hasilnya hadis ini adalah shahih. Pada masa itu ilmu sains untuk mengungkap kebenaran dari matan hadis tersebut belum ada, tetapi dari hasil penelitian sanadnya sudah menyakinkan bahwa matan hadis yang disabdakan Nabi itu diyakini akan keshahihannya dan kebenarannya. Penelitian dari Muhammad Auhaj Muhammad, seorang insiyur kimia penelitiannya yang berjudul $A$ study on the Chemical Composition and Medical Uses of The Urine of Some of the Arabian Camles komponen-komponen kimia dan kegunaan medis terhadap air kemih unta Arab. Pada penelitian tersebut membicarakan bahwa penggunaan air kemih unta untuk keperluan pengobatan penyakit sudah dilakukan sejak berabad-abad yang lalu. Hasil eksperimen dari penelitian tersebut menetapkan sebagai berikut: Pertama, Air kemih unta memiliki tingkat kekentalan tinggi (osmolality) dibandingkan dengan air kemih kambing, sapi dan manusia. Kedua, Air kemih unta banyak mengandung potasium dan protein. Ketiga, Air kemih unta memliki fungsi dan manfaat dan efek pengobatan yang jelas untuk 
menyembuhkan beberapa penyakit yang disebabkan virus dan bakteri. Keempat, Air kemih unta digunakan untuk mengobati pembekuan darah pada pembuluh darah. Karena dapat menguraikan zat penyebab pembekuan darah tersebut, yaitu Febrin. ${ }^{51}$

Penelitian tersebut menyimpulkan bahwa adanya bukti ilmiah yang membenarkan pada hadis Nabi tentang manfaat air susu dan air kemih unta untuk pengobatan berbagai penyakit. ${ }^{52}$ Ibnu Sina dan Ar-Razi adalah dau dokter zaman dulu yang terkenal, keduanya mengobati pasiennya dengan menggunakan air susu dan air kemih unta. Ibnu Sina meyakini bahwa air kemih unta efektif menyembuhkan limpa yang membengkak (splenomegali). Di zaman modern air kemih unta dimanfaatkan untuk mengobati penyakit liukimia dan kanker lambung. Air kemih unta selain mengandung antibiotik juga mengandung sistem kekebalan dengan kadar tinggi sehingga dapat membasmi jamur, bakteri dan virus.

Kandungan air kemih unta ini juga berhasil dijadikan antibiotik berstandar internasional, hal ini dibuktikan oleh hasil penelitian yang dituangkan dalam tesis Manna Al-Qaththan mahasiswa bimbingan Ahlam Al-Audhi Dosen Jurusan Sains Fakultas Pendidikan (Kampus Puteri) di jeddah. Ahlam Al-Audhi bekerja sama dengan Nahid Haekal melakukan penyelidikan penggunaan air kemih unta dalam pengobatan, beliau menggunakan air kemih unta untuk pengobatan penyakit jamur kulit dan melakukan uji coba untuk membunuh virus TBC dengan air kemih unta. Antibiotik yang berasal dari air kemih unta menurut Ahlam Al-Audhi memiliki keunggulan tersendiri, air kemih unta memiliki salinitas tinggi dengan kadar urea rendah, hal ini menjadikan antibiotik yang terbuat dari air kemih unta tidak berbahaya jika tersimpan di suhu tinggi, berbeda dengan antibiotik lainnya jika disimpan di suhu tinggi maka khasiat antibiotiknya akan rusak.

Pola kritik matan yang digunakan para ulama muhaditsin dan peneliti-peneliti Islam dalam mengkaji matan hadis tentang air

51 Dadang Sudrajat, Ensiklopedia Mukjizat Ilmiah Hadits Nabi (binatang darat dan laut) (bandung: syigma publishing, 2010).

52 Sudrajat, 15.

TAJDID vol. 18, No. 2, Juli - Desember 2019 | 169 
kemih unta ini menunjukkan integrasi keilmuan dalam melakukan penelitian ke shahihan dan keotentisitasnya. Ilmu sains sangat berperan dalam mengungkap kebenaran kandungan air kemih unta untuk menyembuhkan berbagai penyakit sesuai apa yang sudah dikatakan oleh Nabi saw. Menurut Ahmad Abdullah Ahmadani Dekan Fakultas Kedokteran Jazirah, Sudan. Bahwa air kemih unta banyak mengandung potassium, albumin (zat putih telur), dan magnesium. Menurut dia penyakit busung air disebabkan oleh kurangnya Albumin dan magnesium dan ternyata kedua zat itu terdapat didalam kandungan air kemih unta.

\section{Penutup}

Integrasi keilmuan dalam kritik matan hadis merupakan kajian studi hadis atau kritik matan hadis yang menggunakan berbagai disiplin ilmu. Pada kajian kritik matan hadis mengenai kandungan air kemih unta dikritik menggunakan ilmu sosial humaniora dan ilmu sains dalam meninjau keotentisitas matan tersebut. Hasil dari kritik matan hadis tentang air kemih unta yang sudah dilakukan oleh para ulama muhaditsin, ilmuan-ilmuan muslim, para dokter, dosen dan para peneliti membuktikan bahwa kandungan air kemih unta dapat menyembuhkan berbagai penyakit sesuai dengan apa yang sudah disampaikan Nabi saw didalam matan tersebut. Ilmu sains dan ilmu sosial humaniora dalam hal ini sangat membantu dalam membuktikan keotentikan matan hadis tersebut.

Ilmu hadis dengan ilmu sosial maupun sains pada dasarnya tidak terpisahkan satu dengan yang lain. Untuk mengkaji ilmu hadis akan lebih ideal jika mempertemukan, mendialogkan dan mensintesiskan agar ditemukan pemikiran-pemikiran yang baru dan solutif atas beragam permasalahan. Dalam proses integrasi ini, hadis dijadikan objek material yang didekati dan dikaji dengan ilmu sosial seperti sosiologi, antrologi, ilmu sejarah dan ilmu geografi. Pada matan hadis tertentu seperti manfaat air kemih unta untuk mengobati berbagai penyakit maka ilmu sains yang akan membuktikannya. Melalui bantuan ilmu sosial dan sains tersebut diharapkan mampu melahirkan makna-makna konstektual yang siap diterapkan dan dipahami oleh masyarakat muslim secara luas. Inilah 
tujuan dari integrasi keilmuan matan hadis dengan ilmu sosial maupun sains agar sampai pada tujuan muliatersebut.

\section{Daftar Pustaka}

Abdullah, M. Amin. Islamic studies dalam paradigma integrasiinterkoneksi: sebuah antologi. Yogyakarta: SUKA Press, 2007.

-----,, "Multidisiplin, Interdisiplin, dan Transdisiplin Ilmu Pengetahuan dan Riset pada Pendidikan Tinggi Masa Depan." Dalam Prosiding Konferensi Integrasi-Interkoneksi Islam dan Sains, 1:xi. Yogyakarta: Fakultas Sains dan Teknologi UIN Sunan Kalijaga Yogyakarta, 2018. sunankalijaga . org / prosiding.

-----, "Religion, Science, and Culture: An Integrated, Interconnected Paradigm of Science." Al-Jami'ah: Journal of Islamic Studies 52, no. 1 (8 Juni 2014): 175-203. https://doi.org/10.14421/ajis.2014.521.175-203.

Abdullah, Muhammad Amin. "Islamic Studies in Higher Education in Indonesia: Challenges, Impact and Prospects for the World Community." Al-Jami'ah: Journal of Islamic Studies 55, no. 2 (15 Desember 2017): 391-426. https://doi.org/10. 14421/ajis.2017.552.391-426.

Afrizal, Lalu Heri. "Selisik Atas Metodologi Kritik Matan Ulama Hadis." Kalimah: Jurnal Studi Agama Dan Pemikiran Islam 14, no. 2 (30 September 2016): 191-218. https://doi.org/ 10. 21111/klm.v14i2.612.

Afwadzi, Benny. "Hadis di Mata Para Pemikir Modern: Telaah Buku Rethinking Karya Daniel Brown.” Jurnal Studi Ilmu-Ilmu alQur'an dan Hadis 15 (2014): 238.

------, "Integrasi ilmu-ilmu alam dan ilmu-ilmu sosial dengan pemahaman hadis Nabi: Telaah atas konsepsi, aplikasi, dan implikasi." Theologia 28, no. 2 (Desember 2017): 351-90.

-----, "Membangun Integrasi Ilmu-Ilmu Sosial Dan Hadis Nabi." Jurnal Living Hadis 1, no. 1 (6 Mei 2016): 101-28. https://doi.org/10.14421/livinghadis.2016.1070.

Ahamad, Syed Rizwan, Abdul Qader Alhaider, Mohammad Raish, dan Faiyaz Shakeel. "Metabolomic and Elemental Analysis of

TAJDID Vol. 18, No. 2, Juli - Desember 2019 | 171 
Camel and Bovine Urine by GC-MS and ICP-MS." Saudi Journal of Biological Sciences 24, no. 1 (1 Januari 2017): 23-29. https://doi.org/10.1016/j.sjbs.2015.09.001.

Akib, Nasri. "Kesahihan Sanad Dan Matan Hadits: Kajian IlmuIlmu Sosial." Shautut Tarbiyah 15, no. 1 (1 Mei 2009): 102-19. https://doi.org/10.31332/str.v15i1.103.

Alfatih Suryadilaga, Muhammad. Ulumul Hadis. Yogyakarta: kalimedia, 2015.

Ali, Nizar. "Memahami Hadis Nabi: Metode dan Pendekatan." Yogyakarta: Center for Educational Studies and Development (CESaD) YPI Al-Rahmah, 2001.

Alma'arif, Alma'arif. "Hermeneutika Hadis Ala Fazlur Rahman." Jurnal Studi Ilmu-Ilmu Al-Qur'an Dan Hadis 16, no. 2 (2015): 243-64. https://doi.org/10.14421/qh.2015.\%x.

Amrulloh, Amrulloh. "Kontribusi M. Syuhudi Ismail Dalam Kontekstualisasi Pemahaman Hadis." Mutawatir: Jurnal Keilmuan Tafsir Hadith 7, no. 1 (1 Juni 2017): 76-104. https://doi.org/10.15642/mutawatir.2017.7.1.76-104.

Arsyad, Azhar. "Buah Cemara Integrasi dan Interkoneksitas Sains dan Ilmu Agama." Hunafa: Jurnal Studia Islamika 8, no. 1 (2011): 1-25.

Asriady, Muhammad. "Metode Pemahaman Hadis." Ekspose: Jurnal Penelitian Hukum Dan Pendidikan 16, no. 1 (13 April 2019): 314-23. https://doi.org/10.30863/ekspose.v16i1.94.

Baedhowi, Baedhowi. "Islamologi Terapan Dan Problema Aplikasinya: (Mengkaji Pemikiran Mohammed Arkoun).” AlJami'ah: Journal of Islamic Studies 41, no. 1 (16 Juni 2003): 133-52. https://doi.org/10.14421/ajis.2003.411.133-152.

Bustamin, M. Isa H.A. Salam. Metodologi kritik hadis. jakarta: PT RajaGrafindo Persada, 2004.

Eickelman, Dale F. “dkk, al Qur’an Sains, dan Ilmu Sosial,” 2010. Habuddin, Ihab. "Konstruksi Gagasan Feminisme Islam Khaled M. Abou El-Fadl: Relevansinya Dengan Posisi Perempuan Dalam Keluarga.” Al-Ahwal: Jurnal Hukum Keluarga Islam 5, no. 2 (26 September 2016): 1-30.

172 | TAJDID vol. 18, No. 2, Juli - Desember 2019 
Hakim, Luqmanul. "Fenomena Inkar Sunnah dalam Perkembangan Sejarah.” Innovatio VII, no. 14 (2008): 346-64.

Hasibuan, M. Idham Aditia. "Kontribusi Sains Dalam Menentukan Kualitas Hadis.” EDU-RILIGIA: Jurnal Ilmu Pendidikan Islam Dan Keagamaan 1, no. 3 (17 Oktober 2017). http: // jurnal.uinsu.ac.id/index.php/eduriligia/article/view/955.

Hudaya, Hairul. "Metodologi Kritik Matan Hadis Menurut AlAdlabidari Teori ke Aplikasi." Jurnal Ilmiah Ilmu Ushuluddin 13, no. 1 (2016): 29-40.

Idlibī, Șalāḥ al-Dīn ibn Aḥmad. Metodologi kritik matan hadis. Gaya Media Pratama, 2004.

Ismail, Mohd Yusuf. "Peranan Sains Moden dalam Interaksi teks Hadis: Penelitian Terhadap Hadis Berkaitan Penciptaan Janin Manusia," 2016.

-----, "Peranan Sains Moden Dalam Interaksi Teks Hadis: Penelitian Terhadap Hadis Berkaitan Penciptaan Janin Manusia." Journal Of Hadith Studies 1, no. 1 (31 Desember 2016). http://journalofhadith.com/ index.php/johs/ article /view/4.

Ismail, Muhammad Syuhudi. Kaedah kesahihan sanad hadis: telaah kritis dan tinjauan dengan pendekatan ilmu sejarah. Bulan Bintang, 1988.

Ismail, T.M.S.T., R. Baru, A.F. Hassan, A.Z.B. Salleh, dan M.F.M. Amin. "The matan and sanad criticisms in evaluating the hadith." Asian Social Science 10, no. 21 (2014): 152-58. https://doi.org/10.5539/ass.v10n21p152.

Juriono, Juriono. "Metode Kritik Matan Mushthafa As-Siba'i Dalam Kitab as-Sunnah Wa Makanatuha Fi at-Tasyri‘ Al-Islami." ATTAHDIS: Journal of Hadith Studies 1, no. 1 (31 Maret 2017). http://j urnal.uinsu.ac.id/index.php /attahdits / article/view/ 650 .

Kodir, Aceng Abdul. "Hadis dan Analisis Aliran Politik Rijal: Studi Geo-Politik Terhadap Aliran Shi 'ah dan Nasb." Journal of Qur'an and Hadith Studies 1, no. 2 (2012): 277-95.

Lukman, Fadhli. "Integrasi-Interkoneksi Dalam Studi Hadis Disertasi Di Uin Sunan Kalijaga Yogyakarta.” RELIGIA, 20 
Februari 2017, 1-11. https://doi.org/ 10.28918/ religia. v $19 \mathrm{i} 2.746$.

Luthfi, Khabibi Muhammad. "Kritik Matn Sebagai Metode Utama dalam Penelitian Kesahihan Hadis Nabi." Islamic Review: Jurnal Riset dan Kajian Keislaman 4, no. 2 (2015): 199-224.

Majid, Abdul. "Hermeneutika Hadis Gender (Studi Pemikiran Khaled M. Abou El Fadl Dalam Buku Speaking in God's Name; Islamic Law, Authority And Women).” Al-Ulum 13, no. 2 (1 Desember 2013): 293-320.

N, Sora. "Pengertian Sains Secara Singkat Dan Jelas." Pengertian Apapun (blog), 25 Januari 2015. http:// www. pengertianku. net/2015/01/pengertian-sains-secara-singkat-dan-jelas.html.

Nadhiran, Hedhri. "Kritik Sanad Hadis: Tela'ah Metodologis." Jurnal Ilmu Agama UIN Raden Fatah 15, no. 1 (2014): 91-109. Nasrulloh, Nasrulloh. "Kontekstualitas dan Historisitas Matan Hadis-Hadis Peperangan Terhadap Non-Muslim." Jurnal THEOLOGIA 28, no. 1 (14 September 2017): 165-82. https://doi.org/10.21580/teo.2017.28.1.1322.

Qomarullah, Muhammad. "Metode Kritik Matan Hadis Muhammad Tahir Al-Jawabi Dalam Kitab: Juhud alMuhaddisin Fi Naqd Matan al-Hadis an-Nabawi Asy-Syarif." Al Quds: Jurnal Studi Alquran Dan Hadis 2, no. 1 (1 Juni 2018): 51-64. https://d oi.org /10.29240 / alquds.v2i1.390.

Salamah, Norhidayati. Kritik Teks Hadis: Analisis Tentang ar Riwayah bi al-Ma'na dan Implikasinya bagi Kualitas Hadis. Yogyakarta: teras, 2009.

Sari, Fitri. "Urine unta (studi nalar hadisdan pendekatan medis)," 2018. Universitas Islam Negeri Sumatea Utara Medan. Retrieved from http://repository.uinsu.ac.id

Sinaga, Hasanuddin. "Metode Pemahaman Hadis Ulama Mutaqaddimīn (Tinjauan terhadap Metode Pemahaman Ahli Hadis dan Fuqahā’).” Refleksi 18, no. 1 (24 September 2019): 66-77. https://doi.org/10.15408/ref.v18i1.12676.

Soebahar, Erfan, Edi Daenuri, dan Arizal Firmansyah. "Mengungkap Rahasia Buah Kurma Dan Zaitun Dari Petunjuk 
Hadis Dan Penjelasan Sains." Ulul Albab Jurnal Studi Islam 16, no. 2 (2015): 191-214.

Soekanto, Soejono. Sosiologi: Suatu Pengantar. Jakarta: Raja Grafindo Persada, 2012.

Sudrajat, Dadang. Ensiklopedia Mukjizat Ilmiah Hadits Nabi (binatang darat dan laut). bandung: syigma publishing, 2010.

Suhendra, Ahmad. "Hermeneutika Hadis Khaled M. Abou El Fadl."

Mutawatir 5, no. 2 (1 Desember 2015): 343-62. https:// doi .org/10.15642/mutawatir.2015.5.2.343-362.

Sumbulah, Umi. Kritik Hadis Pendekatan Historis Metodologis. malang: UIN-Malang Press, 2008.

Supian, Aan. "Konsep Syadz Dan Aplikasinya Dalam Menentukan

Kualitas Hadis." Nuansa 8, no. 2 (14 Desember 2015). https://doi.org/10.29300/nuansa.v8i2.396.

Suryadi, Suryadi. Metode Kontemporer Memahami Hadis Nabi

Perspektif Muhammad al-Ghazali dan Yusuf al-Qardhawi.

Yogyakarta: ElSAQ Press, 2008.

------, "Pentingnya Memahami Hadis Dengan Mempertimbangkan Setting Historis Perspektif Yūsuf Al-Qaraḍawī.” Jurnal Living Hadis 1, no. 1 (6 Mei 2016): 29-50. https://doi.org/10.14421/livinghadis.2016.1067.

-----, "Rekonstruksi Kritik Sanad Dan Matan Dalam Studi Hadis." Esensia: Jurnal Ilmu-Ilmu Ushuluddin 16, no. 2 (1 Oktober 2015): 177-86. https://doi.org/ 10.14421/ esensia.v16i2.996.

Suryadilaga, Muhammad Alfatih. Metodologi Penelitian Hadis. Yogyakarta: Teras, 2009.

-----, "Pembacaan Hadis Dalam Perspektif Antropologi." Al Qalam 34, no. 2 (2017): 265-86.

Syahroni, Ahmad. "Pembahasan Metode Pemahaman Hadis Imam Syafi'i." Aktualita: Jurnal Penelitian Sosial Keagamaan 9, no. 1 (24 Juli 2019): 1-16.

Tangngareng, Tasmin. "Methodology of Hadith Content Criticism: A Study on the Thought of Salah al-Din Bin Ahmad al-Adlabi." Esensia: Jurnal Ilmu-Ilmu Ushuluddin 17, no. 1 (1 April 2016): 97-110. https://doi.org/10.14421/ esensia.v17i1 . 1281.

TAJDID vol. 18, No. 2, Juli - Desember 2019 | 175 
Yaqin, Ainol. "Integrasi Ilmu Agama Dan Sains (kajian Atas Pemikiran Al-Ghazālî̀)." Islamuna: Jurnal Studi Islam 3, no. 1 (1 Juli 2016): 37-55. https://doi.org/10.19105/ islamuna .v 3i1.946.

Zailani, Zailani. "Rekontruksi Tradisi Islam (Studi Pemikiran Muhammed Arkoun Tentang Sunnah)." Jurnal Ushuluddin 18, no. 2 (1 Desember 2012): 198-207. https:/ /doi.org /10.24014/jush.v18i2.709.

Zainol, N.Z.N., dan L.A. Majid. "Studied controversial issues and analyze Nasr Hamid Abu Zayd thoughts contained in voice of exile: Reflections on Islam." Advanced Science Letters 23, no. 5 (2017): 4951-54. https://doi.org/10.1166/asl.2017.8973. 